\title{
BANGUNAN UNTUK BERNAFAS SOLUSI POLUSI UDARA DI JAKARTA
}

\author{
Kenzo Therin ${ }^{1)}$, J.M. Joko Priyono Santoso ${ }^{21}$ \\ 1)Program Studi S1 Arsitektur, Fakultas Teknik, Universitas Tarumanagara, kenzo.315170120@stu.untar.ac.id \\ 2) Program Studi S1 Arsitektur, Fakultas Teknik, Universitas Tarumanagara, jokop@ft.untar.ac.id
}

\begin{abstract}
Abstrak
Proyek Bangunan untuk bernafas ini yang berada di Jl. Perintis, Mega Kuningan, merupakan proyek yang diharapkan mampu menyelesaikan permasalahan polusi udara di area tersebut secara arsitektur. Proyek ini merupakan bangunan yang menerapkan sistem pertukaran udara secara alami menggunakan media tanaman untuk menyerap gas karbon dioksida yang dihasilkan oleh gas emisi kendaraan bermotor. Bangunan ini juga bertujuan sebagai proyek pionir di Jakarta untuk menjadi inspirasi dan referensi perancangperancang pada masa mendatang dalam menyelesaikan permasalahan udara dari sisi Arsitektur. Masalah yang menurut saya terjadi saat ini di kota Jakarta saat ini adalah belum adanya proyek yang memiliki tujuan untuk mengurangi tingkat polusi udara di Jakarta. Hal ini dapat dilihat dari minimnya jumah fasilitas-fasilitas ramah lingkungan yang dapat digunakan secara umum. Dapat dilihat juga dari bangunan-bangunan di jakarta yang "mematikan" karena sangat minim penghijauan pada bangunan karena perancangperancang masih hanya mementingkan efisiensi dibandingkan pelestarian alam. Maka dari itu proyek saya ini dengan judul "Bangunan untuk Bernafas Solusi Polusi Udara di Jakarta" ini diperlukan untuk memberikan nafas berupa gas oksigen segar kepada masyarakat dan penduduk sekitar bangunan.
\end{abstract}

Kata kunci: bangunan bernafas; polusi udara; keberlanjutan

\begin{abstract}
This Breathing Building Project which is located on Jl. The pioneer, Mega Kuningan, is a project that is expected to be able to solve the problem of air pollution in the area architecturally. This project is a building that implements a natural air exchange system using plant media to absorb carbon dioxide gas produced by motor vehicle emissions. This building also aims as a pioneer project in Jakarta to be an inspiration and reference for future designers in solving air problems from an architectural perspective. The problem that I think is happening in the city of Jakarta at this time is that there are no projects that aim to reduce the level of air pollution in Jakarta. This can be seen from the minimal number of environmentally friendly facilities that can be used in general. It can also be seen from the buildings in Jakarta which are "deadly" because there is very little greenery in buildings because the designers are still only concerned with efficiency over nature conservation. Therefore, my project with the title "Building for Breathing Air Pollution Solutions in Jakarta" is needed to provide breath in the form of fresh oxygen gas to the community and residents around the building.
\end{abstract}

Keywords: breathing building; air pollution; sustainability

\section{PENDAHULUAN}

\section{Latar Belakang}

Polusi merupakan masalah yang sering kali disepelekan di kota Jakarta dan di kota lain nya. Hal ini sering disepelekan seakan tidak berdampak pada ekosistem yang sudah ada pada daerah tersebut. Perkembangan zaman yang pesat ini menimbulkan peningkatan besar pada aktifitas industri dan transportasi berbasi bahan bakat fossil yang dimana akan memicu timbulnya pencemaran udara / 
polusi udara yang akan berdampak pada kesehatan wilayah industri dan kota-kota besar padat penduduk lain nya yang masih banyak menggunakan kendaraan pribadi untuk berpergian. Pencemaran udara ini memiliki dampak yang sangat ekstrem terhadap kesehatan seperti gangguan saluran pernafasan, penyakit jantung, kanker berbagai organ tubuh, gangguan reproduksi da hipertensi. Pencemaran udara yang saling sering ditemukan adalah gas karbon monoksida (CO), Nitrogen Oksida (NO), Sulfur Oksida (Sox), dan partikel lain nya. Zat pencemar ini juga akan menetap di udara dan akan menimbulkan hujan asam ketika hujan turun. Menurut hasil penelitian pusar studi lingkungan (PSL) IPB Bogor, Hujan asam sudah banyak terjadi di sekitar wilayah jabodetabek dengan pH 5,3. Hujan sama berdampak sangat buruk pada manusia dan juga lingkungan sekitar. Hujan asam merusak tanaman yang dikenai hujan tersebut. Tumbuhan yang terkena hujan asam dengan frekuensi 3 kali seminggu dengan $\mathrm{pH}$ air sekitar 5 akan menyebabkan hilangnya lapisan lilin pelindung daun tumbuhan. Oleh sebab itu hujan asam dengan frekuensi tinggi seperti yang sering terjadi di kota jakarta akan menyebabkan tanaman menjadi rusak, kerdil dan tidak produktif sama sekali. Bahkan menurut manahan Huajn asam dengan pH dibawah 4,0 akan menyebabkan pohon menjadi kerangas dan akhirnya mati. Selain untuk mahkluk hidup, hujan asam juga mempercepat bangunan- bangunan di jabodetabek yang menggunakan bahan metal menjadi cepat korosi dan korosi tersebut dapat menimbulkan beberapa penyakit ke dalam hidup manusia. Polusi udara mempengaruhi kesehatan manusia, hewan, dan bumi ini. Tanpa kami sadari bahwa sekitar tujuh juta orang meninggal secara prematur karena penyakit yang disebabkan oleh polusi udara. Seketaris Jendral PBB, Antonio Guterres, dalam pesan nya megatakan bahwa polusi udara adalah resiko lingkungan terbesar bagi kesehatan manusia. Polusi udara dengan kondisi sekarang akan bertambah parah pada masa mendatangnya jika tidak di tuntaskan secara total mulai dari generasi sekarang.

\section{Rumusan Permasalahan}

Dari latar belakang tersebut, terdapat beberapa masalah yang ditemukan dan dapat menjadi bahan penelitian antara lain:

a. Bagaimana cara arsitektur beradaptasi untuk mengurangi polusi udara yang terjadi di Jakarta?

b. Bagaimana peran arsitektur mengubah pola hidup masyarakat yang terbiasa memproduksi polusi udara?

c. Bagaimana arsitektur mampu menjadi pedoman untuk rancangan bangunan pada masa mendatang?

\section{Tujuan}

Tujuan proyek rancangan ini adalah menjadi proyek pionir atau penerobos di Jakarta yang dapat menjadi acuan perancang lain nya untuk bangunan-bangunan pada masa mendatang dalam menyelesaikan permasalahan polusi udara yang dihasilakn dari kebiasaan kehidupan manuasia sehari-hari yang tidak disadari memberikan pengaruh buruk kepada lingkungan sekitar yang dapat di kemas semaksimal mungkin kedalam satu bangunan perancangan

\section{KAJIAN LITERATUR}

\section{Ekologi}

Ekologi berasal dari bahasa yunani oikos (rumah atau tempat hidup) dan logos (ilmu). Secara harafiah ekologi merupakan ilmu yang mempelajari organisme dalam tempat hidup. Maka dapat di katakan bahwa ekologi mempelajari hubungan timbal balik antara organisme dengan lingkungannye. Ekologi hanya bersifat eksploratif tanpa melakukan percobaan. Maka ekologi hanya mempelajari apa yang terjadi pada alam. Pada saat ini dengan berbagai kepentingan dan keperluan, ekologi berkembang sebagai ilmu yang tidak hanya mempelajari apa yang ada dan terjadi pada alam tetapi juga berkembang menjadi ilmu yang mempelajari struktur dan fungsi ekosistem (alam), sehingga datadata tersebut dapat di analisis oleh para ilmuwan dan para ilmuwan tersebut dapat memberikan jawaban terhadap berbagai kejadian alam yang terjadi. Sebagai contoh ekologi diharpkan dapat 
memberikan jawaban terhadap terjadi nya tsunami, banjir, tanah longsor, penyakit DBD, pencemaran, efek rumah kaca, kerusakan hutan dan lain-lain.

\section{Pengertian Pencemara Udara}

Pencemaran udara adalah suatu kondisi dimana kehadiran satu atau lebih substansi kimia, fisika atau biologi di atmosfer bumi dalam jumlah yang membahayakan. Bahaya ini dapat mempengaruhi kesehatan manusia, hewan, dan tumbuhan, mengganggu estetika dan kenyamanan, atau merusak properti. Polusi duara merupakan salah satu jenis dari pencemaran lingkungan hidup selain pencemaran tanah, air, dan suara.

Pencemaran udara adalah perusakan terhadap kualitas udara yang ada di sekitar kita. Kerusakan ini dapat terjadi di karenakan sumber biologis maupun non-biologis. Pencemaran udara biasanya terjadi paling sering karena asap kendaraan bermotor, asap pabrik, limbah industri, limbah rumah tangga.

\section{Sumber Pencemaran Udara}

Menurut para ahli, pencemaran udara ada umumnya itu terdiri dari dua sumber utama yaitu:

a. Sumber Pencemaran udara ilmiah, misalkan akibat letusan gunung berapi, atau juga karena kebakaran hutan yang terjadi secara alami, nitrifikasi, denitrifikasi biologis.

b. Sumber pencemaran udara yang berasal atas perbuatan manusia sendiri misalnya dari gas buangan transportasi yang digunakan sehari-hari, gas emisi pabrik yang tidak di filtrasi. Zat penyebab pencemaran udara yang bersumber dari kegiatan manusia antara lain gsa karbon monoksida, oksida sulfur, Oksida Nitrogen, Partikel, Hidrokarbon, Oksida fotokimia termasuk ozon dan lain-lain nya

\section{Macam-macam Pencemaran Udara}

Macam pencemaran pada umumnya ada dua yaitu :

a. Pencemaran udara primer, yaitu substansi pencemaran yang di timbulkan langsung dari sumber pencemaran yang dihasilkan. Salah satu contoh pencemaran udara primer adalah karbon monoksida karena zat tersebut merupakan zat hasil pembakaran langsung yang dihasilkan.

b. Pencemaran udara sekunder yaitu substansi udara pencemar terbentuk dari adanya reaksi pencemaran udara primer di atmosfer. Salah satu contoh pencemaran udara sekunder adalah pembentukan ozon dalam proses fotokimia.

\section{Penanggulan Pencemaran Udara}

Dalam menyelesaikan masalah pencemaran udara di dunia dapat dilakukan beberapa cara sebagai solusi sebagai berikut :

a. Menggunakan transportasi umum ketika ingin berpergian. Hal ini harus ditingkatkan kesadaran masyarakat untuk menggunakan kendaraan umum masal sebagai alat transportasi sehari-hari

b. Penghematan energi seperti mematikan kipas angin, lampu, AC saat tidak diperlukan atau keluar. Sejumlah besar bahan bakar fosil dibakar untuk menghasilkan listrik, ketika kita mengurangi penggunaan listrik maka kita juga mengurangi penggunaan bahan bakar fosil dan menyelamatkan kualitas udara

c. Menerapkan dan memahami konsep 3R yaitu reduce, reuse, recycle. Tidak membuang barangbarang yang bagi kita tidak berguna padahal masih bisa digunakan untuk hal lain, misalnya kerajinan tangan, dll. Bahkan untuk beberapa bahan masih dapat di kumpulkan dan didaur ulang kembali untuk dijadikan barang produk lain yang bisa di pakai kembali.

d. Menggunakan sumber energi terbarukan dan ramah lingkungan. Teknologi energi terbarukan ramah lingkungan seperti matahari, angin, panas bumi. Di berbagai negara lain nya telah memberikan hibah kepada konsumen yang tertarik untuk memasang panel surya untuk rumah mereka. 


\section{Definisi dan Terminologi Green Building}

Menurut GBCl (2011),secara definisi green building adalah bangunan yang sejak di mulai dalam tahap perencanaan, pembangunan, pengoperasian hingga dalam pemeliharaannya memperlihatkan aspekaspek dalam melindungi, menghemat, serta mengurangi penggunaan sumber daya alam, menjaga mutu dari kualitas udara di ruangan, dan memperhatikan kesehatan penghuninya yang semuanya berpegang pada kaidah pembangunan yang berkelanjutan. Menurut Sastra dan Marlina (2006), perumahan adalah kelompok rumah yang berfungsi sebagai lingkungan tempat tinggal atau hunian yang dilengkapi dengan prasarana lingkungan yaitu kelengkapan dasar fisik lingkungan, misalnya penyediaan air minum, pembuangan sampah, listrik, telepon, jalan, yang memungkinkan lingkungan perumahan berfungsi sebagaimana mestinya

\section{Konsep dan Dasar Teori}

Menurut Hartanto dalam Dedy (2011), konsep green building mulai berkembang sejak tahun 1970. Konsep ini mulai dikembangkan sebagai bentuk tanggapan krisis energi yang terjadi dan keprihatinan masyarakat terhadap kondisi lingkungan yang sedang terjadi. Green Building adalah konsep yang juga biasa lebih dikenal sebagai bangunan hijau yang berkelanjutan. Banyak pihak yang setuju bahwa green building harus memenuhi persyaratan lokasi sistem rancangan, renovasi, dan pengoprasian yang menganut prinsip hemat energi serta berdampak positif bafi lingkungan, ekonomi, dan sosial.

Menurut GBCl (2011), ketika kita menjalankan dan menerapkan proses green home, ada empat aspek utama yang perlu dipertimbangkan dalam membangun green home. Yaitu aspek kesehatan, aspek penggunaan material, aspek penghematan energi, dan aspek penggunaan air. Untuk memperhatikan aspek kesehatan dalam pembangunan green home, kita perlu menggunakan bahanbahan bangunan dan furnitur yang tidak beracun serta produk yang dapat meningkatkan kualitas udara dalam ruangan yang ditinggali. Bahan yang dimaksud adalah bahan bebas emisi, rendah atau non - Volatile Organic Compounds (VOC). Dan tahan air untuk mencegah datang nya kumah dan mikroba lainnya. Kualitas udara sebuah ruangan juga bisa dibantu dengan sistem ventilasi yang baik dan alat pengatur kelembapan udara.

Maka dari itu sebenarnya material yang diperlukan untuk membangun green home harus diperoleh dari alam, yang merupakan sumber energi terbarukan yang dikelola secara berkelanjutan, atau bahan bangunan yang didapat secara lokal untuk mengurangi biaya transportasi. Daya tahan material bangunan juga harus layak dan tetap teruji secara teknisnya. Mengandung unsur bahan daur ulang, dan dapat digunakan kembali atau di daur ulang.

Sedangkan dari sisi energi harus diperhatikan adalah penerapan panel surya diyakini dapat mengurangi biaya listrik bangunan. Selain itu, bangunan juga selayaknya dilengkapi jendela untuk menghemat penggunaan energi (terutama untuk lamu serta AC) Pada siang hari, kita bisa membuka jendela untuk sirkulasi udara dan mengurangi pemakaian listri. Jendela juga tentunya meningkatkan kesehatan dan produktivitas pengguna ruang di dalam nya. Green Building juga harus menggunakan lampu hemat energi, peralatan listrik hemat energi. Oleh karena itu penempatan titik lampu amat sangat lah penting dalam perencanaan karena kesalahan dalam meletakan titik lampu dapat meningkatkan penggunaan listrik dan membuat bangunan menjadi lebih boros.

Aspek lain nya yang harus diperhatikan dalam green building adalah penggunaan air. Untuk menghemat penggunaan air, ada berbagai cara yang dapat dilakukan secara arsitektur seperti menerapkan sistem tangkapan air hujan pada bangunan, cara ini akan mendaur ulang air yang misalknya dapat digunakan untuk menyiram tanaman atau menyiram toilet, selain itu diperlukan peralatan hemat air, seperti pancuran aur yang aliran airnya rendah, tidak menggunakan kran otomatis untuk menghemat penggunaan air secara langsung. 


\section{Kriteria Penilaian Green Building}

Suatu bangunan dapat disebut sudah menerapkan konsep bangunan hijau apabila berhasil melalui suatu proses evaluasi untuk mendapatkan sertifikasi 7 bangunan hijau. Di dalam evaluasi tersebut tolok ukur penilaian yang dipakai adalah sistem peringkat yang dipersiapkan dan disusun oleh Green Building Council yang ada di negara-negara tertentu yang sudah mengikuti gerakan bangunan hijau $(\mathrm{GBCl}, 2011)$. Setiap negara tersebut mempunyai sistem peringkat masing-masing. Seperti beberapa yang akan dijelaskan berikut:

a. BREEAM (Building Research Establishment Enviromental Assessment Method)-UKGBC BREEAM merupakan standar penilaian green building di Inggris, pertama kali diluncurkan pada tahun 1990. Sekitar 200.000 bangunan telah memiliki sertifikat penilaian BREEAM. BREEAM menetapkan standar kriteria pada tahap desain, konstruksi, dan penggunaan, kriteria ini sudah diakui secara luas sebagai penilaian kinerja bangunan ramah lingkungan. Kriteria BREEAM mengacu pada beberapa aspek yang berhubungan dengan penggunaan energi, air, kesehatan, polusi transportasi, bahan, limbah, ekologi dan proses manajemen.

b. LEED (Leadership In Energy And Environment Design)-USGBC LEED adalah standar penilaian lingkungan tingkat sertifikasi green building di USA. LEED bertujuan untuk membuat standar bangunan hijau yang layak agar dapat diterapkan di setiap bangunan dan dapat digunakan tidak hanya di lingkungan sekitar saja. Ada enam kriteria penilaian bangunan ramah lingkungan yang dievaluasi oleh LEED. Berikut empat diantaranya yaitu Sustainable Sites, Efisiensi Air, Energi dan Atmosphere, serta Bahan dan Sumber Daya. LEED bersertifikat bangunan yang dirancang untuk menurunkan biaya operasi dan meningkatkan nilai aset, mengurangi limbah yang dikirim ke tempat pembuangan sampah, menghemat energi dan air, menjadi tempat yang sehat dan aman bagi penghuni, mengurangi emisi gas rumah kaca yang berbahaya.

c. Greenstar-GBCA Greenstar adalah standar penilaian lingkungan tingkat sertifikasi green building di Australia. Tujuan Greenstar adalah untuk mempromosikan pembangunan berkelanjutan. Dengan menerapkan program green building, pada tahap desain dan dalam penoperasian. Kriteria Greenstar di dasarkan 8 pada sistem yang telah ada yaitu BREEAM dan LEED. Kriteria Greenstar mengacu pada beberapa aspek yang terkait dengan manajemen, kualitas lingkungan, energi, air, transportasi, material, ekologi, emisi dan inovasi.

d. Greenmark-SGBC Greenmark adalah standar penilaian industri konstruksi Singapura terhadap bangunan ramah lingkungan. Hal ini dimaksudkan untuk mempromosikan keberlanjutan dalam lingkungan binaan dan meningkatkan kesadaran lingkungan di kalangan pengembang, desainer dan pembangun ketika mereka mulai konseptualisasi proyek dan desain, serta selama konstruksi.

e. Greenship-GBCl Greenship adalah sistem penilaian yang digunakan sebagai alat bantu bagi para pelaku industri bangunan, meliputi pengusaha, arsitek, teknisi mekanikal elektrikal, desainer interior, teknisi bangunan, lanskaper, serta pelaku lainnya dalam rangka menerapkan praktikpraktik terbaik dan berupaya untuk mencapai standar yang terukur serta dapat dipahami oleh masyarakat umum beserta para pengguna bangunan $(\mathrm{GBCl}, 2011)$. Greenship terdiri dari new building, existing building dan home.

\section{METODE}

\section{Metode Penelitian}

Metode penelitian yang digunakan dalam penulisan jurnal ini adalah dengan teknik pengumpulan data-data melalui literatur, jurnal, artike website yang terkait dengan isu dan teori perancangan yang ada di internet. Pengukuran dan pengambilan data juga dilakukan secara digital melalui google maps, goole earth, berita yang memberikan informasi mengenai tapak yang terpilih.

\section{Metode Desain}

ini sendiri berusaha memberikan solusi terhadap permasalahan iklim di lingkungannya dan berusaha membuat bangunan yang melampaui ekologi. Bangunan ini juga berusaha menghemat energi, 
mereduksi emisi, meningkatkan produksi, meminimalisasi pengeluaran dan meningkatkan nilai tambah bangunan (Design media Publishings Limited, 2010); berkelanjutan, ramah lingkungan, tanggap iklim, sadar energi dan cerdas budaya (Nugroho, 2019). Dalam arsitektur hijau ada beberapa kriteria yaitu sebagai berikut :

a. Berkelanjutan (sustainable) yang dimana arsitektur hijau dapat tetap bertahan dan berfungsi seiring dengan perubahan zaman, konsisten terhadap konsepnya yang menyatu dengan alam tanpa adanya perubahan-perubahan yang signifikan tanpa merusak alam sekitar.

b. Ramah Lingkungan : bangunan yang terbangun harus ramah lingkungan, definisi ramah lingkungan ini bukan hanya dalam perusakan lingkungan tetapi juga menyangkut masalah pemakaian energi dalam bangunan.

Sehingga dari keterangan di atas tadi saya akan merancang bangunan yang dimana penghijauan tersebut dapat

\section{DISKUSI DAN HASIL}

Menurut saya, dari hasil analisis dan pembahasan proyek saya dengan judul "Bangunan untuk Bernafas" merupakan proyek yang tepat untuk menyelesaikan permasalahan polusi yang dihasilkan oleh kendaraan bermotor di sekitar Mega Kuningan Barat. Hal ini dikarenakan bangunan ini merupakan pelopor dengan program ruang yang menarik yang akan menjadi pusat perhatian masyarakat sekitar dan jakarta. Program yang terdapat dalam bangunan ada tiga yaitu: 1 . Botanical Garden, Research Center, dan Office Tower. Ketiga program tersebut merupakan program yang saling terhubung secara ruang dan pengguna. Untuk Penjelasan lebih lanjutnya sebagai berikut:

\section{Botanical Garden}

Botanical Garden merupakan taman dengan variasi tanaman kecil hingga besar yang mengisi hampi seluruh lantai 1 bangunan. Pada dalam taman ini sendiri nantinya akan ada beberapa sub-program sendiri seperti garden café. Garden café ini merupakan resto dan café yang berada pada lantai 2 bangunan yang mendapatkan view langsung ke arah botanical garden dan air mancur yang berada di bagian tengahnya. Kemudia ada Sanggar Berfikir yang dimana dapat digunakan pengguna untuk bersantai sambil berfikir untuk menemukan ide-ide baru dalam pekerjaan nya atau tugas yang sedang di kerjakan.

\section{Research Center}

Research Center merupakan area penelitian yang digunakan oleh para pakar dan peneliti untuk menyelesaikan permasalahan polusi di Jakarta. Hal ini dapat berupa pemantauan yang di lakukan maupun pengembangan teknologi untuk mengurangi polusi di Jakarta. Pada bagian ini juga terdapat auditorium besar yang dapat dijadikan area pertemuan untuk membahas permasalahan polusi yang ada di Jakarta atau hal yang berhubungan dengan polusi di Jakarta seperti perubahan iklim di Indonesia. Semua ini bertujuan untuk menyelesaikan permasalahan polusi di Jakarta.

\section{Office Tower}

Office Tower merupakan program pendukung yang dimana untuk memfasilitasi penduduk jakarta yang ingin usaha terutama untuk bisnis start up untuk mengembangkan usaha mereka. Pada office ini mereka tidak akan terikat pada ruangan tertutup dengan meja tapi mereka juga bisa bekerja pada area terbuka seperti botanical garden yang dari awal sudah di rancang untuk mendukung area bekerja orang kantor. 


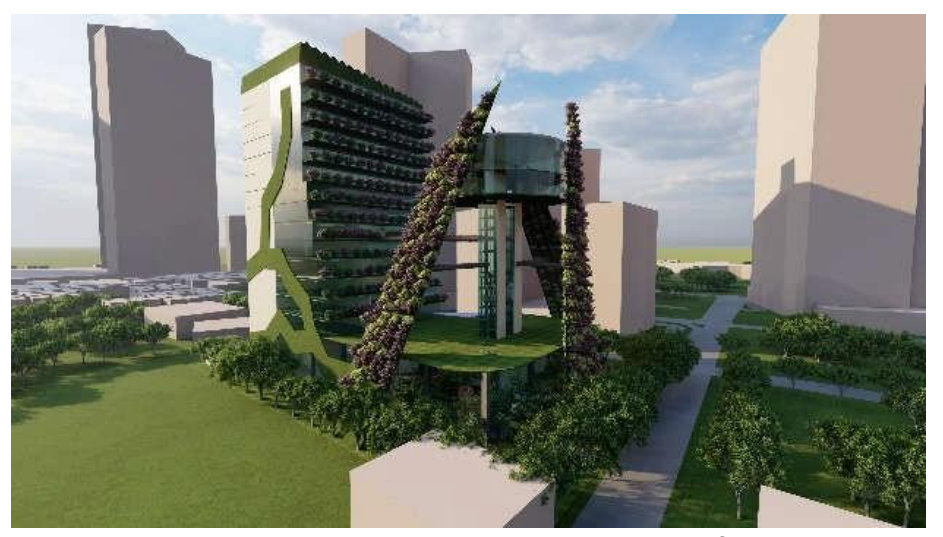

Gambar 1. Bangunan untuk bernafas

Bangunan untuk bernafas ini di bangun dengan rangka baja dan kulit perforated panel yang di lapis dengan tanaman kecil pada bagian fasadnya. Tanaman-tanaman tersebut akan berperan menjadi paru-paru pada daerah tersebut untuk menghirup karbon dioksida hasil gas emisi kendaraan bermotor dan menghembuskan oksigen bersih ke lingkungan yang kemudian akan dapat di hirup oleh penduduk sekitar. Konsep bernafas yang digunakan menggunakan analogi paru-paru yang terdapat dalam tubuh manusia. Bentuk lingkarang yang terkesan mengambang pada bagian depan bangunan bertujuan untuk menarik perhatian publik sehingga bangunan ini dapat menjadi contoh perancangan pada rancangan nya di masa mendatang. Tanaman kecil yang menutupi bagian fasad dibuat berwarna warni juga untuk bertujuan menarik perhatian penduduk atau pengunjung bangunan. Untuk skala kota Jakarta, bangunan ini masih belum bisa menyelesaikan permasalahan polusi udara di Jakarta, tetapi jika bangunan mendatang menggunakan desain rancangan seperti ini, maka tidak bisa di pungkiri bahwa permasalahan polusi di Jakarta akan cepat selesai.

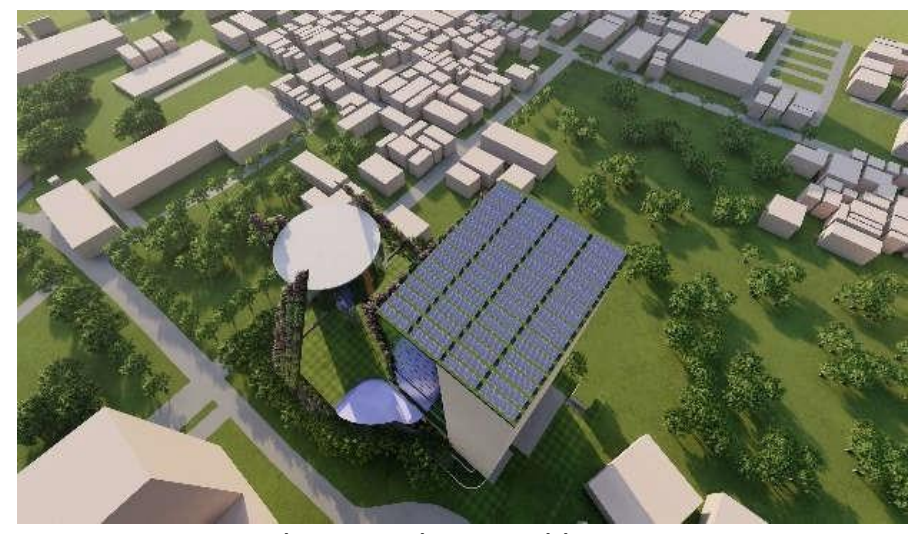

Gambar 2. Solar Panel bangunan

Bangunan untuk bernafas ini menerapkan green building standard $\mathrm{GBCl}$ pada perancangan nya. Misalnya pada orientasi peletakan bangunan. Orientasi bangunan mengikuti arah orientasi timurbarat sehingga bangunan mendapat pencahayaan matahari alami secara maksimal. Hal ini merupakan hal yang sangat penting pada bangunan ini karena terdapat banyak tanaman. Ketika peletakan bangunan ini salah dan terdapat bagian yang tidak mendapatkan cahaya matahari langsung maka tanaman pada bangunan terutama pada botanical garden tidak akan bertahan lama dan mati. Kemudian juga terdapat standar penggunaan material. Material yang digunakan pada bangunan ini di dominasi oleh penggunaan kaca low-E yang diaman kaca tersebut akan memasukan cahaya alami matahari dan menangkal panas matahari sehingga suhu pada bagian dalam bangunan tidak akan terlalu tinggi dan hal ini dapat menghemat penggunaan listrik pada bagian AC. Kemudian bangunan ini juga memaksimalkan penggunaan solar panel untuk sumber energi listrik dan memanfaatkan teknologi smart building seperti sensor gerak, sensor cahaya yang dapat secara 
otomatis memotong penggunaan listrik pada bangunan. Peletakan solar panel ini sudah disusun agar solar panel mendapatkan cahaya maksimal dari matahari sepanjang hari sehingga penggunaan nya akan maksimal untuk menghasilkan listrik pada bangunan. Bangunan ini juga menggunakan sistem penampungan air hujan dan filtrasi air bekas untuk digunakan kembali pada bangunan. Jadi air kotor yang sudah digunakan akan di filtrasi dan digunakan kembali pada bangunan sehingga tidak menggunakan banyak sumber daya alam dari sekitar.

\section{KESIMPULAN DAN SARAN}

\section{Kesimpulan}

Bangunan untuk bernafas ini dapat dinilai efektif untuk mengurangi polusi pada area sekitar bangunan saja. Untuk menyelesaikan permasalahan polusi di Jakarta, maka bangunan perancangan pada masa mendatang harus juga mengikuti gaya perancangan ini agar polusi di jakarta dapat di selesaikan secara arsitektural.

\section{REFERENSI}

Green building standards and certification system, 8 Mei 2019, https://www.wbdg.org/resources/green-building-standards-and-certification-systems https://www.ngbs.com/the-ngbs-green-promise https://www.coa.gov.in/show_img.php?fid=150 https://www.hon.org/issues/226 https://issuu.com/nai010publishers/docs/habitiat_ecologythinking_introductie_issuu_nai010 https://core.ac.uk/download/pdf/236408788.pdf https://then24.com/2021/07/02/sustainable-architecture-a-business-far-beyond-ecology/ https://www.ansgroupglobal.com/blog/history-and-development-ecological-architecture https://hmcarchitects.com/news/the-top-6-sustainable-architecture-strategies-for-public-buildingdesign-2018-10-03/ 